Akuntansi dan Manajemen

Vol. 16, No. 2, 2021, Hal. 142-152

\title{
Kecenderungan Kecurangan (Fraud) Yang Dipersepsikan Melalui Keadilan Organisasi dan Peran Sistem Pengendalian Intern
}

\author{
Lisa Amelia Herman1, Syafira Ramadhea JR ${ }^{2}$ \\ 1 Jurusan Akuntansi, Politeknik Negeri Padang \\ Email: lisa.ameliaherman@gmail.com \\ ${ }^{2} J u r u s a n$ Akuntansi, Politeknik Negeri Padang \\ Email: syafira.ramadhea@gmail.com
}

\begin{abstract}
Public trust is the main capital of the banking business in carrying out its function of collecting and distributing public funds. Bank management must make efforts to maintain and maintain this trust in order to gain sympathy from prospective customers, such as obeying existing regulations and not making mistakes that cause irregularities and fraud. Fraud can be carried out by internal or external parties. One of the motivations for someone to commit fraud is a sense of justice. An individual who feels that he is being treated unfairly tends to act against the goals of the organization. In addition, the ineffectiveness of the internal control system allows opportunities to commit fraud that will have a negative impact on the company. This study aims to determine the effect of organizational justice and the role of the internal control system on fraud. Respondents as many as 164 employees of the main branch office of a government bank in the city of Padang were used as samples. The method that will be applied to analyze the data is multiple linear regression analysis with SPSS v.25 program. The results show that organizational justice and the role of the internal control system affect organizational fraud. This research can have implications for organizations to provide behavioral justice for each employee so that employee intentions to commit fraud can be avoided.
\end{abstract}

Keywords : fraud, organisational justice, internal control

\begin{abstract}
ABSTRAK
Kepercayaan masyarakat merupakan modal utama bisnis perbankan dalam menjalankan fungsinya menghimpun dan menyalurkan dana masyarakat. Manajemen bank harus melakukan upaya untuk menjaga dan mempertahankan kepercayaan tersebut agar memperoleh simpati dari calon nasabah, seperti menaati peraturan yang ada dan tidak melakukan kesalahan yang menyebabkan terjadinya penyimpangan dan kecurangan. Kecurangan dapat dilakukan oleh pihak internal maupun eksternal. Salah satu motivasi seseorang melakukan kecurangan adalah rasa keadilan. Seorang individu yang merasa diperlakukan tidak adil cenderung melakukan tindakan yang bertentangan dengan tujuan organisasi. Selain itu, ketidakefektivan sistem pengendalian internal memungkinkan terbukanya peluang untuk melakukan kecurangan yang akan berdampak negatif bagi perusahaan. Penelitian ini bertujuan mengetahui pengaruh keadilan organisasi dan peran sistem pengendalian internal terhadap kecurangan. Responden sebanyak 164 orang karyawan/i kantor cabang utama bank pemerintah di Kota Padang dijadikan sampel. Metode yang akan diterapkan untuk menganalisis data adalah analisis regresi linear berganda dengan program SPSS v.25. Hasil penelitian menunjukkan bahwa keadilan organisasi dan peran sistem pengendalian internal mempengaruhi kecurangan
\end{abstract}


organisasi. Penelitian ini dapat memberikan implikasi bagi organisasi untuk memberikan keadilan perilaku bagi setiap karyawan sehingga niat karyawan untuk melakukan kecurangan dapat dihindari.

Kata kunci : Kecurangan, keadilan organisasi, internal control

\section{Pendahuluan}

Bank merupakan perusahaan penyedia jasa keuangan yang berfungsi sebagai perantara masyarakat yang membutuhkan dana (lack of funds) dengan masyarakat yang kelebihan dana (surplus of funds), disamping jasa-jasa keuangan lainnya. Kepercayaan masyarakat merupakan faktor utama bisnis perbankan. Manajemen bank harus berupaya menjaga dan mempertahankan kepercayaan tersebut agar memperoleh simpati dari calon nasabah seperti selalu menaati peraturan dan tidak melakukan kesalahan yang menyebabkan terjadinya penyimpangan dan kecurangan.

Organisasi apa pun rentan terhadap tindakan kecurangan, yaitu tindakan penipuan atau kecurangan lain yang dilakukan untuk mendapatkan sesuatu yang berharga dari orang lain secara ilegal, baik dengan kekuatan fisik atau dengan tipu daya [1]. Literatur penelitian menunjukkan bahwa baik organisasi swasta maupun publik telah mengalami menjadi korban perilaku ini. Organisasi bisnis terus menghadapi masalah kecurangan, dan memerangi masalah ini adalah sebuah tantangan. Kecurangan dapat dilakukan oleh pihak internal maupun eksternal. Kecurangan akuntansi dalam bisnis biasanya melibatkan pihak internal perusahaan. Kecurangan yang dilakukan oleh pihak internal perusahaan adalah kecurangan yang sulit dihindari [5]. Kecurangan dapat dilakukan baik oleh manajemen atau oleh karyawan perusahaan sendiri. Jika ada bias tujuan di antara individu dan perusahaan, kecurangan sangat mungkin terjadi. Dampak dari penipuan akuntansi akan menyebabkan penurunan akuntabilitas manajemen dan akan menghasilkan peningkatan pemantauan biaya terhadap manajemen seperti yang diusulkan oleh pemegang saham [4].

Hasil Survei Fraud Indonesia tahun 2019 oleh Associations of Certified Fraud Examiners (ACFE) menunjukkan total kerugian akibat fraud mencapai Rp873,43 Milliar untuk tiga jenis fraud, yaitu korupsi, penyalahgunaan aset dan fraud laporan keuangan (ACFE, 2020). Sebesar 50,2\% pelaku fraud adalah dari manajemen dan karyawan dan sebesar 38\% fraud dilakukan secara kolutif oleh empat atau lebih pelaku. Perusahaan milik negara (BUMN) termasuk bank pemerintah menempati posisi kedua $(31,8 \%)$ lembaga yang paling dirugikan akibat fraud setelah lembaga pemerintahan. Korupsi merupakan jenis fraud yang sering terjadi yaitu sebesar $69,9 \%$ dari total kasus. Dengan tingkat keparahan fraud ini, penting bagi para pemimpin organisasi untuk memahami akar penyebab perilaku ini dalam hal siapa yang melakukan fraud dan bagaimana mengelola risiko secara proaktif [11].

Menurut Undang-Undang Nomor 20 Tahun 2001, terdapat 30 jenis korupsi yang dikelompokkan menjadi tujuh kategori, antara lain: (1) tindakan dan perbuatan yang merugikan keuangan negara dan perekonomian negara; (2) tindakan dan perbuatan suap dan sogok; (3) iindakan dan penggelapan di kantor; 
(4) tindakan pemerasan; (5) Penipuan dalam proses pengadaan barang dan jasa; (6) adanya benturan kepentingan dalam pengadaan barang dan jasa dan (7) Gratifikasi. Pada instansi pemerintah sering terjadi kecurangan.

Cressey (1953) dalam [14] menjabarkan Teori Fraud Triangle mengatakan bahwa tiga faktor pendorong kecurangan, yaitu tekanan (Pressure), peluang (Opportunity), dan rasionalisasi (Rationalization). Teori inilah yang mendasari penentuan variabel pada penelitian ini. Persepsi keadilan organisasi dan sistem pengendalian intern sebagai variabel yang digunakan merupakan proksi dari unsurunsur Fraud Triangle diatas.

Tekanan (Pressure) merupakan hal yang memotivasi individu/karyawan untuk melakukan kecurangan. Tekanan dapat berupa tekanan keuangan maupun non keuangan, serta dapat disebabkan pula oleh tekanan pribadi maupun tekanan dari organisasi. Dijelaskan oleh beberapa penelitian, hal-hal yang terkait dengan tekanan antara lain, kebutuhan hidup yang mendesak, penghasilan kurang, gaji yang tidak sesuai [9]. Persepsi keadilan organisatoris merupakan tekanan yang menjadi penyebab seorang melakukan fraud [10].

Rasionalisasi (rationalization) merupakan suatu sikap atau rasionalisasi yang dapat diterima secara moral perlu terjadi sebelum perilaku curang muncul. Penting untuk diketahui bahwa tindakan kecurangan terkadang tidak memandang tindakan mereka sebagai tindakan yang tidak etis; mereka hanya membenarkan tindakan mereka dianggap etis sebelum terjadi kecurangan. Dengan kata lain, rasionalisasi memungkinkan pelaku melihat tindakan ilegalnya dapat diterima. Jika seseorang tidak dapat membenarkan tindakan tidak etis, tidak mungkin dia akan melakukannya, dan terlibat dalam tindakan kecurangan [11]. Orang itu, bagaimanapun, dapat merasionalisasi tindakan tersebut dengan cara yang berbeda menggunakan berbagai pembenaran. Contoh: "Saya hanya meminjam", "Organisasi mampu membelinya", "tidak dapat bonus atau kenaikan gaji", "Semua orang menjadi kaya, jadi mengapa saya tidak?" dan "Ini tidak terlalu material".

Peluang membuka pintu terjadinya kecurangan, dan insentif serta rasionalisasi dapat menarik orang ke arah itu. Namun, berdasarkan teori fraud diamond, orang tersebut juga harus memiliki kemampuan untuk mengenali keterbukaan pintu sebagai peluang dan memanfaatkannya [12]. Model integrasi untuk Organizational Justice Perceptions (OJP) sebagai hubungan untuk mendorong dan memotivasi yang rasional untuk berperilaku curang dan kualitas prosedur pengendalian internal sebagai suatu proksi untuk melakukan kecurangan (COSO, 2004). Keadilan dalam suatu organisasi dan penerapan sistem pengendalian intern merupakan hal penting dalam menciptakan lingkungan kerja yang kondusif. Persepsi mengenai keadilan yang dirasakan karyawan dalam lingkungan perusahaan relatif terhadap apa yang mereka kontribusikan.

Menurut teori Maslow, keadilan merupakan unsur yang dianggap penting dan menjadi landasan motivasi bagi suatu individu [6]. Keadilan organisasi menekankan bagaimana reward, insentif, pengakuan, pekerjaan, dan sanksi dalam suatu lembaga (organisasi) dialokasikan secara adil dan proporsional berdasarkan karakteristik sosial demografis yang ada. Teori ini didasarkan pada asumsi bahwa seseorang dimotivasi oleh keinginan untuk diperlakukan secara adil dalam pekerjaan. 
Berdasarkan teori kesetaraan dan keadilan, konsep keadilan organisasi dirangkum dalam dua sub-dimensi, yaitu: keadilan distributif dan prosedural [10]. Keadilan distributif adalah konsep psikologis yang berhubungan dengan keadilan yang dirasakan dari hasil, sedangkan keadilan prosedural mengacu pada sejauh mana proses pengambilan keputusan dilakukan dan dianggap adil. Kedua dimensi dihubungkan oleh konsep keadilan dan berimplikasi pada perilaku karyawan sebagai akibat dari persepsi mereka tentang perlakuan yang adil.

Sedangkan [3] membagi keadilan organisasi menjadi tiga kategori, yaitu keadilan distribusi, keadilan prosedural, dan keadilan interaksional. Secara umum, karyawan akan mengevaluasi kewajaran dalam tiga kondisi, seperti, pendapatan yang diperoleh dari organisasi (keadilan distribusi), kebijakan formal atau proses pencapaian yang dialokasikan (keadilan prosedural), dan perlakuan yang diambil oleh pengambil keputusan di antara personel dalam organisasi (organisasional fariness). Persepsi tentang keadilan distribusi, prosedural, dan interaksional dapat saling terkait dengan berbagai hasil pekerjaan tertentu, seperti pelaksanaan kegiatan, perilaku, dan sikap kerja. Keadilan organisasi adalah sebuah kondisi yang mengarahkan individu untuk memiliki keyakinan bahwa mereka diperlakukan adil atau tidak adil oleh organisasi. Individu yang merasa diperlakukan tidak adil akan muncul kekecewaan yang mengarah untuk melakukan tindakan yang bertentangan dengan tujuan organisasi. Dengan demikian, hipotesis dalam penelitian ini adalah:

H1. Keadilan organisasi berpengaruh negatif terhadap kecurangan.

Penyebab munculnya tindakan kecurangan selain ketidakadilan dalam perusahaan adalah kurang efektifnya Sistem Pengendalian Intern (SPI) perusahaan. Salah satu upaya pencegahan kecurangan yaitu membangun struktur pengendalian intern yang baik dan mengefektifkan aktivitas pengendalian tersebut [15]. Pasal 3 ayat 1 POJK No. 39/POJK.03/2019 tentang Penerapan Strategi Anti Fraud Bagi Bank Umum bahwa bank wajib menerapkan Strategi Anti Fraud yang merupakan bagian dari kebijakan strategis Bank yang penerapannya diwujudkan dalam sistem pengendalian Fraud. Penerapan Strategi Anti Fraud merupakan bagian dari penerapan manajemen risiko, khususnya yang terkait dengan aspek SPI.

Sistem pengendalian intern adalah suatu sistem pengendalian yang terdiri dari kebijakan dan proses yang dirancang untuk memberikan manajemen jaminan yang wajar bahwa perusahaan mencapai tujuan dan sasarannya [2]. Ernest \& Young sebagai salah satu konsultan terkemuka, memberikan awardness kepada organisasi atau perusahaan yang ada di dunia agar mempunyai kesadaran akan pengendalian untuk menghindari ancaman dan resiko yang muncul dalam lingkungan organisasi.

SPI yang efektif menjadi komponen penting dalam manajemen bank dan menjadi dasar kegiatan operasional bank yang sehat dan aman, membantu pengurus menjaga aset bank, menjamin tersedianya pelaporan keuangan dan manajerial yang dapat dipercaya, meningkatkan kepatuhan bank terhadap ketentuan dan peraturan yang berlaku, serta mengurangi risiko terjadinya kerugian, penyimpangan dan pelanggaran aspek kehati-hatian. Selain itu, pengendalian yang cukup dan efektif dapat memperkecil celah bagi para pelaku kecurangan untuk 
melakukan tindakan yang merugikan perusahaan dan menguntungkan mereka sendiri. Semakin efektif SPI maka kecurangan dalam suatu perusahaan semakin dapat dicegah.

Jika SPI lemah mengakibatkan kekayaan bank tidak terjamin keamanannya, informasi akuntansi yang ada tidak diteliti dan tidak dapat dipercaya, tidak efisien dan efektifnya kegiatan operasional bank serta tidak dipatuhinya kebijakan yang ditetapkan manajemen. Selain itu adanya kemampuan untuk melakukan dan menyembunyikan kecurangan akibat kurangnya pengawasan atau enforcement pada bank, kontrol bank tidak berhasil mencegah terjadinya praktik kecurangan, ditambah kurangnya pengawasan manajemen, dan faktor tekanan (pressure) berkaitan dengan pikiran/pandangan dan kepentingan pegawai yang takut kehilangan pekerjaan atau jabatan sehingga orang jujur pun punya motif untuk melakukan kecurangan.

Penipuan adalah suatu bentuk tindakan yang dilakukan seseorang sebagai penggunaan jabatan/pekerjaan untuk memperoleh kekayaan pribadi melalui pelaksanaan penyalahgunaan sumber daya atau kekayaan organisasi yang mempekerjakannya. Menurut [8], penipuan dan penurunan kinerja karyawan di perusahaan dan organisasi sering terjadi karena kurangnya motivasi terhadap kepemimpinannya. Menurutnya kinerja pegawai di perusahaan diakibatkan karena pegawai merasa di 'terpaksa' pada perusahaan atau organisasi. Ketidakadilan cenderung merupakan pemicu kecurangan yang dilakukan oleh karyawan. Dengan demikian, hipotesis dalam penelitian ini adalah:

H2. Sistem pengendalian intern berpengaruh negatif terhadap kecurangan.

\section{Metode Penelitian}

Penelitian ini tergolong penelitian kausatif yang meneliti hubungan sebab akibat untuk menganalisis pengaruh variabel keadilan organisasi dan peran sistem pengendalian intern terhadap kecurangan (fraud). Populasi adalah semua bank pemerintah di Kota Padang dan sampel diambil pada Kantor Cabang Utama (KCU) bank pemerintah dengan responden karyawan/i yang bekerja disana. Sampel ditentukan menggunakan teknik simple random sampling. Total responden ditentukan menggunakan rumus Slovin sehingga diperoleh 244 orang dari 627 orang total sampel. Responden terkumpul sebanyak 164 orang atau sebesar $67 \%$ dari total responden. Peneliti menggunakan data subjek berupa opini, sikap, pengalaman, atau karakteristik dari seseorang yang menjadi responden. Peneli mengambil data primer yang diperoleh dengan melakukan survei lapangan melalui kuesioner.

Variabel penelitian terdiri dari: Keadilan Organisasi - KO (X1); Sistem Pengendalian Intern - SPI (X2); dan Kecurangan - KC (Y). Instrumen penelitian yang digunakan dalam penelitian ini diambil dari teori yang ada. Variabel-variabel yang diukur dalam kuesioner ini mencakup: 1) keadilan organisasi; 2) sistem pengendalian intern; dan 3) kecurangan. Peneliti menyusun sendiri pertanyaan sesuai dengan teori. Untuk variabel Instrumen kuesioner berjumlah 32 pernyataan, 
terdiri dari 12 item untuk variabel KC, 11 item untuk variabel KO, dan 9 item untuk SPI.

Variabel keadilan organisasi diukur melalui tiga indikator, yaitu keadilan distributif, keadilan prosedural dan keadilan interaksional. Ketiga indikator ini dijabarkan kedalam 11 item pernyataan kuesioner. Untuk variabel sistem pengendalian intern diukur melalui tiga indikator, yaitu SPI melalui sistem, SPI melalui prosedur dan SPI melalui struktur organisasi. Ketiga indikator ini dijabarkan kedalam 9 item pernyataan kuesioner. Demikian juga dengan variabel kecurangan diukur melalui tiga indikator, yaitu kecurangan laporan keuangan (finansial statement fraud), penyalahgunaan aset (aset misappropriation), dan korupsi (corruption). Ketiga indikator SPI ini dijabarkan kedalam 12 item pernyataan kuesioner. Semua variabel diukur dengan menggunakan skala likert dengan pilihan lima jawaban.

Instrumen telah melewati uji validitas dan reliabilitas. Uji asumsi klasik untuk menilai kelayakan model regresi, meliputi uji normalitas, heterokedastisitas, dan multikolinearitas. Teknik analisis data melalui analisis deskriptif dan analisis data dengan Uji $\mathrm{F}$ dan koefisien determinasi. Hipotesis diuji menggunakan analisis regresi linear berganda dengan $a=0,05$ dengan model regresi sebagai berikut :

$$
\mathrm{Y}=\alpha+\beta_{1} \mathrm{X}_{1+} \beta_{2} \mathrm{X}_{2}+\varepsilon \text {. }
$$

\section{Hasil Penelitian dan Pembahasan}

Hasil analisis deskriptif berdasarkan kualifikasi pendidikan diperoleh responden terbanyak berpendidikan Strata 1 / Diploma 4, sebanyak 85 orang (52\%). Responden terbanyak dari segi jenis kelamin adalah perempuan, sebesar 96 orang (59\%). Dari segi masa kerja, responden terbanyak dengan masa kerja > 10 tahun, yaitu 72 orang (44\%). Statistik deskriptif seperti tabel dibawah ini menunjukkan variabel KC memiliki nilai rata-rata sebesar 31,52 dengan standar deviasi 5,096. Variabel KO dengan nilai rata-rata sebesar 47,95 dengan standar deviasi 4,513. Sedangkan variabel SPI memiliki nilai rata-rata sebesar 39,38 dengan standar deviasi 3,713.

Tabel 1. Statistik deskriptif

\begin{tabular}{l|l|r|r|r|r}
\hline & N & Minimum & Maximum & Mean & Std. Deviation \\
\hline KC & 164 & 21 & 43 & 31,52 & 5,096 \\
\hline KO & 164 & 38 & 56 & 47,95 & 4,513 \\
\hline SPI & 164 & 33 & 45 & 39,38 & 3,713 \\
\hline Valid N (listwise) & 164 & & & & \\
\hline
\end{tabular}

Sumber : Data primer yang diolah, 2021

Semua pernyataan kuesioner telah diuji validitas dan reliabiliasnya. Dimana nilai $r_{\text {tabel }}$ untuk n=164 dan df=n-2 (164-2=162) pada signifikansi 0,05 adalah 0,129. Nilai Corrected Item-Total Colleration terendah untuk item variabel KC adalah 0,243, variabel KO adalah 0,533, dan variabel SPI adalah 0,203. Nilai Corrected Item-Total 
Colleration masing-masing item variabel KC, KO dan SPI semuanya di atas $\mathrm{r}_{\text {tabel. }}$ Disimpulkan bahwa seluruh item pernyataan variabel $\mathrm{X}_{1}, \mathrm{X}_{2}$, dan $\mathrm{Y}$ adalah valid.

Nilai cronbach's alpha terendah dari item variabel KC adalah 0.899 , variabel KO adalah 0.906 dan variabel SPI adalah 0.853. Nilai cronbach's alpha terendah dari masing-masing item variabel $\mathrm{KC}$, KO dan SPI semua besar dari 0,70. Dengan demikian, item pernyataan kuesioner (setelah dilakukan uji validitas) dinyatakan reliabel.

Hasil pengujian asumsi klasik diperoleh nilai Test Statistic KolmogorovSmirnov sebesar 0,048 dengan signifikansi 0,200. Nilai signifikan uji normalitas > 0,05 , sehingga data yang digunakan berdistribusi normal dan bisa diteliti lebih lanjut. Nilai VIF yang diperoleh menunjukkan variabel bebas dalam model tidak saling berkorelasi. Hasil uji Glejser menunjukkan tingkat signifikansi untuk variabel KO adalah 0,424 dan variabel SPI adalah 0,175. Nilai signifikansi untuk variabel KO dan SPI semuanya besar dari $\alpha 0,05$, jadi disimpulkan bahwa model regresi yang digunakan terbebas dari heteroskedastisitas. Nilai VIF untuk variabe KO dan SPI adalah 1,006 dan nilai toleran untuk variabe KO dan SPI adalah 0,994. Nilai VIF setiap variabel bebas $<10$ dan tolerance value $>0,10$ yang menunjukkan tidak adanya korelasi antara sesama variabel bebas dalam model regresi. Disimpulkan bahwa tidak terdapat masalah multikolinearitas diantara sesama variabel bebas.

Hasil pengujian regresi linear berganda menunjukkan nilai $F_{\text {hitung }}$ sebesar 69,364 signifikan pada 0,000. Nilai $F_{\text {tabel }}$ dengan df $1=3-2=2$ dan df $2=164-3=161$ adalah 3,05. Jadi $F_{\text {hitung }}>F_{\text {tabel }}$ dengan nilai signifikansi $0.000<0.05$, Sehingga model regresi sudah fix, dan dapat digunakan untuk memprediksi variabel-variabel penelitian. Dengan demikian, keadilan organisasi dan sistem pengendalian intern secara simultan berpengaruh terhadap kecurangan. Dari tampilan output model summary pada tabel dibawah, besarnya Adjusted $R$ Square adalah 0,430. Kontribusi variabel KO dan SPI sebesar 43\%. Sedangkan 57\% ditentukan oleh faktor lain diluar model yang tidak terdeteksi dalam penelitian ini.

Tabel 2. Hasil Uji F dan Koefisien Determinasi

\begin{tabular}{cccc}
\hline No. & Keterangan & Indikator & Nilai \\
\hline 1. & Uji F & F $_{\text {Hitung }}$ & 62,364 \\
& & FTabel $_{\text {Tar }}$ & \\
2. & Koefisien Determinasi & Adjusted $R$ Square & 0,430 \\
\hline \multicolumn{4}{l}{ Sumber : Data primer yang diolah, 2021}
\end{tabular}

Hasil pengujian koefisien regresi linear berganda menunjukkan nilai konstanta sebesar 78,875, mengindikasikan bahwa jika variabel independen yaitu KO dan SPI adalah nol maka nilai KC sebesar konstanta 78,875. Koefisien KO sebesar 0,625 berarti setiap peningkatan keadilan organisasi satu satuan mengakibatkan penurunan kecurangan sebesar 0,625 satuan. Koefisien SPI sebesar 0,441 berarti setiap peningkatan SPI satu satuan mengakibatkan penurunan KC sebesar 00,441 satuan. Hasil pengujian koefisien regresi membentuk model regresi sebagai berikut:

$$
\mathrm{Y}=\mathbf{7 8 , 8 7 5}-0,625 \mathrm{X}_{1}-0,441 \mathrm{X}_{2}
$$


Uji t dilakukan untuk mengetahui seberapa besar pengaruh variabel independen terhadap variabel dependen secara parsial. Pengujian hipotesis dilakukan dengan membandingkan nilai thitung dan ttabel. Hipotesis diterima jika thitung $>$ ttabel atau nilai sig $<\alpha 0,05$. Nilai ttabel pada $\alpha 0,05$ adalah 1,654 . Untuk variabel $\mathrm{KO}$, nilai t hitung adalah 9,334 dan nilai sig adalah 0,000. Dikatakan bahwa thitung $>$ tabel yaitu 9,334 $>1,654$ atau nilai sig $0,000<\alpha 0,05$. Nilai koefisien regresi $\beta$ dari variabel $\mathrm{X}_{1}$ bernilai negatif yaitu 0,625 . Disimpulkan bahwa keadilan organisasi berpengaruh signifikan dan negatif terhadap kecurangan. Sehingga hipotesis pertama dari penelitian ini diterima.

Pengujian hipotesis untuk variabel SPI dengan nilai thitung adalah 5,417 dan nilai sig adalah 0,045. Dikatakan bahwa thitung $>t_{\text {tabel }}$ yaitu 5,417 $>1,654$ atau nilai sig $0,045<\alpha 0,05$. Nilai koefisien regresi $\beta$ dari variabel $\mathrm{X}_{2}$ bernilai negatif yaitu 0,441 . Disimpulkan bahwa sistem pengendalian intern berpengaruh signifikan negatif terhadap kecurangan. Sehingga hipotesis kedua diterima. Semakin baik penerapan sistem pengendalian intern maka semakin rendah tindakan kecurangan pada perusahaan.

Tabel 3. Hasil Uji Koefisien Regresi Linear Berganda Coefficients ${ }^{\mathrm{a}}$

\begin{tabular}{lr|r|r|r|r|r|r}
\hline & \multicolumn{2}{c}{$\begin{array}{c}\text { Unstandardized } \\
\text { Coefficients }\end{array}$} & \multicolumn{2}{c|}{$\begin{array}{c}\text { Standardized } \\
\text { Coefficients }\end{array}$} & t & Sig. & \multicolumn{2}{c}{$\begin{array}{c}\text { Collinearity } \\
\text { Statistics } \\
\text { Model }\end{array}$} & \multicolumn{1}{c}{ B } & Std. Error & Beta & & & Tolerance & VIF \\
\hline 1 (Constant) & 78,875 & 4,377 & & 18,022 &, 000 & & \\
\hline KO &,- 625 &, 067 &,- 554 & $-9,334$ &, 000 &, 994 & 1,006 \\
\hline SPI &,- 441 &, 081 &,- 321 & $-5,417$ &, 000 &, 994 & 1,006 \\
\hline
\end{tabular}

a. Dependent Variable: KC

Sumber : Data primer yang diolah, 2021

Hasil pengujian hipotesis pertama menunjukkan bahwa semakin tinggi keadilan dalam organisasi maka semakin rendah tindakan kecurangan pada perusahaan. Hasil ini sejalan dengan penelitian [4] yang menemukan bahwa keadilan organisasi berpengaruh negatif terhadap kecurangan. Kecurangan bisa dilakukan oleh karyawan dalam organisasi yang merasa bahwa mereka sedang diperlakukan tidak adil dalam organisasi. Karyawan yang merasa telah menerima keadilan dari organisasi mereka akan cenderung untuk menghindari kecurangan, karena mereka memiliki loyalitas lebih kepada perusahaan. Sebaliknya, karyawan yang berpikir bahwa mereka mendapatkan ketidakadilan dalam organisasi akan cenderung curang untuk mendapatkan keadilan bagi mereka. Ketidakadilan yang dirasakan seperti itu akan mendorong karyawan untuk melakukan kecurangan.

Selain itu, ketika seseorang mendapat perlakuan yang tidak adil maka akan menimbulkan kecemburuan antar karyawan dan mereka akan melakukan perlawanan protes atau membalasnya dengan berdusta dan melakukan kecurangan [13]. Oleh karena itu, apabila keadilan pada karyawan terpenuhi dengan baik, maka produktivitas dan hasil kerja karyawan akan meningkat dan menghilangkan motivasi untuk melakukan tindakan yang merugikan perusahaan sehingga mendorong tercapainya tujuan yang telah ditetapkan. 
Hasil pengujian hipotesis kedua menemukan bahwa semakin baik penerapan sistem pengendalian intern maka semakin rendah tindakan kecurangan pada perusahaan. Menurut [4], organisasi dengan pengendalian internal yang baik akan dapat mendeteksi dan menghindari kecurangan dalam organisasi. Pengendalian internal yang dikelola dengan baik dalam sebuah organisasi akan menciptakan suasana yang kondusif bagi setiap lapisan karyawan, jadi karyawan merasa puas dan nyaman bekerja, dan tidak akan termotivasi untuk melakukan kecurangan.

Hasil temuan ini sejalan dengan penelitian [10] dan [8] yang menemukan bahwa terdapat pengaruh negatif antara efektivitas pengendalian internal dan keadilan organisasi terhadap kecurangan karyawan. Penelitian [10] menyimpulkan bahwa keadilan organisasi dan kualitas pengendalian intern dapat menekan terjadinya kecurangan karyawan. Penelitian ini menyediakan bukti empiris secara periodik pentingnya kualitas prosedur pengendalian intern dan keadilan dari kebijakan organisasi sebagai keadilan prosedural dan distributif di tempat kerja untuk pencegahan kecurangan oleh karyawan. Persepsi keadilan distributif rendah terkait dengan contoh sabotase, dan persepsi keadilan prosedural yang rendah terkait dengan balas dendam dan pertimbangan litigasi. Persepsi yang buruk tentang keadilan organisasi cenderung meningkatkan tekanan atau memotivasi karyawan untuk membalas melalui penipuan karyawan. Selanjutnya, ketika persepsi keadilan organisasi rendah, karyawan lebih mudah merasionalisasi melakukan kecurangan karena mereka lebih cenderung merasa dendam terhadap majikan yang "tidak adil" dan mengurangi rasa bersalah dalam melakukannya.

Ketika keadilan organisasi dianggap rendah, kemungkinan akan menciptakan ketidakpuasan, kebencian dan bahkan kemarahan terhadap organisasi. Akibatnya, sikap seperti itu memotivasi berbagai jenis perilaku menyimpang di tempat kerja yang akan merugikan organisasi (seperti: keterlambatan, ketidakhadiran, pencurian dan sabotase) serta yang ditujukan pada individu dalam tempat kerja (seperti intimidasi, ejekan atau pelecehan terhadap orang lain). Karyawan melihat kejadian perlakuan di tempat kerja yang cenderung tidak adil sebagai tanda tidak hormat terhadap individu, menciptakan perasaan permusuhan yang pada gilirannya dapat meningkat menjadi rasa negatif terhadap organisasi, yang mengarah ke penyimpangan di tempat kerja.

\section{Kesimpulan dan Saran}

Berdasarkan hasil analisis data yang dilakukan, diperoleh hasil penelitian sebagai berikut:

a. Keadilan organisasi secara negatif mempengaruhi kecurangan dengan nilai signifikansi 0,000. Artinya semakin tinggi keadilan yang diperoleh karyawan dalam perusahaan maka semakin rendah tindakan kecurangan pada perusahaan tersebut.

b. Sistem pengendalian internal secara negatif mempengaruhi kecurangan dengan nilai signifikansi 0,000 . Artinya semakin baik penerapan sistem pengendalian intern maka semakin rendah tindakan kecurangan pada perusahaan tersebut. 
Saran yang dapat diajukan untuk penelitian selanjutnya supaya dapat menggunakan variabel lain, seperti gaya kepemimpinan, integritas karyawan, moralitas individu, dan lain-lain. Selain itu, disarankan untuk memperluas populasi penelitian tidak hanya terbatas pada bank pemerintah, tapi juga bank swasta. Penelitian ini diharapkan dapat memberikan implikasi bagi organisasi untuk memberikan keadilan perilaku bagi setiap karyawan sehingga niat karyawan untuk melakukan kecurangan dapat dihindari. Perusahaan juga diharapkan memiliki pengendalian internal yang baik agar tidak terjadi kecurangan yang dapat dilakukan oleh karyawan

\section{Referensi}

[1] Albrecht, C., Turnbull, C., Zhang, Y., \& Skousen, C. J. (2010). The relationship between South Korean chaebols and fraud. Management Research Review, 33(3), 257-268.

[2] Arens, Alvin A. 2008. Auditing dan Jasa Assurance Pendekatan Terintegrasi Jilid I. Erlangga. Jakarta.

[3] Bakshi, Arti dan Ekta Rani. 2009. Organizational Justice Perception As Predictor Of Job Satisfaction An Organization Commitmen. Internasional Journal of Business and Management. Vol: 4. No: 9. Page: 145-154.

[4] Dewi, Ni Nyoman, Sri Rahayu, Trisna Dewi, I Gusti Ayu Agung, Sinta Diarini Dan Ni Made Ernila Junipisa. 2018. The Role Of Internal Control To Minimize The Fraud Caused By Organizational Justice. International Journal of Multidisciplinary Educational Research. Volume 7, Issue 8(1), August 2018. ISSN : 2277-7881; Impact Factor - 5.818; Ic Value:5.16; Isi Value:2.286.

[5] Dewi, Kadek Yuli Kurnia. 2017. Pengaruh Pengendalian Internal dan Integritas pada Kecenderungan Kecurangan Akuntansi Satuan Kerja Perangkat Daerah Kota Denpasar. Ejurnal Akuntansi Universitas Udayana. Vol: 18. No: 2. Hal: $917-$ 941.

[6] Danovan, M. A., Drasgrow, F. \& Munson, L. J. 1998. The Perception of Fair Interpersonal Treatment Scale : Development and Validation of a Measure of Interpersonal Treatment in the Workplace. Journal of Applied Psychology, 83 (5), 683-692.

[7] Dewi, N. N. S. R. T., Rahayu, S., Dewi, T., Ayu, I. G., Sinta, A., Made, N., \& Junipisa, E. (2018). I j m e r. 8(August), 1-13.

[8] Manurung, D., Suhartadi, A. R., \& Saefudin, N. (2015). The Influence of Organizational Commitment on Employee Fraud with Effectiveness of Internal Control and Organizational Justice as a Moderating Variable. Procedia - Social and Behavioral Sciences, 211, 1064-1072. https://doi.org/10.1016/j.sbspro.2015.11.142

[9] Pristiyanti, I. R. (2012). Persepsi Pegawai Instansi Pemerintah Mengenai Faktor-Faktor Yang Mempengaruhi Fraud Di Sektor Pemerintahan. Accounting Analysis Journal, 1(1). https://doi.org/10.15294/aaj.v1i1.707

[10] Rae, K., \& Subramaniam, N. (2008). Quality of internal control procedures: Antecedents and moderating effect on organisational justice and employee 
fraud. Managerial Auditing Journal, 23(2), 104-124. https://doi.org/10.1108/02686900810839820

[11] Ramamoorti, S. (2008). The Psychology and Sociology of Fraud : Integrating the Behavioral Sciences. Issues in Accounting Education, 23(4), 521-533.

[12] Ruankaew, T. (2016). Beyond the Fraud Diamond. International Journal of Business Management \& Economic Research, 7(1), 474-476.

[13] Suhartini, S. (2005). Keadilan dalam Pemberian Kompensasi. Jurnal Siasat Bisnis, edisi(khusus), 103-114. https://doi.org/10.20885/jsb.ed.khus.art7.

[14] Tuanakotta, Theodorus. M. 2007. Akuntansi Forensik dan Audit Investigasi. Seri Departemen Akuntansi: FE UI.

[15] Tunggal. Amin Wijaya. 2010. Dasar-dasar audit intern pedoman untuk auditor baru. Jakarta: Harvarindo.

[16]https://acfe-indonesia.or.id/wp-content/uploads/2021/02/SURVEI-FRAUDINDONESIA-2019.pdf 